\title{
Assessment of the impact of changes in temperature in Biomphalaria glabrata (Say, 1818) melanic and albino variants infected with Schistosoma mansoni (Sambon, 1907)
}

\author{
E. A. F. Camargo ${ }^{a, b *}$, J. T. F. Camargo ${ }^{b}$, M. F. Neves ${ }^{a}$, L. F. Simões ${ }^{a}$, L. A. D. Bastos ${ }^{a}$, \\ L. A. Magalhães ${ }^{a}$ and E. M. Zanotti-Magalhães ${ }^{a}$ \\ ${ }^{a}$ Departamento de Biologia Animal, Instituto de Biologia, Universidade Estadual de Campinas - UNICAMP, \\ CP 6109, CEP 13083-970, Campinas, SP, Brazil \\ ${ }^{\mathrm{b}}$ Centro Regional Universitário de Espírito Santo do Pinhal - UniPinhal, Av. Hélio Vergueiro Leite, s/n, \\ CEP 13990-000, Espírito Santo do Pinhal, SP, Brazil \\ *e-mail: eafcamargo@yahoo.com.br
}

Received: October 8, 2015 - Accepted: May 9, 2016 - Distributed: August 31, 2017

(With 3 figures)

\begin{abstract}
Fluctuations in population density of planorbid hosts of $S$. mansoni are influenced by climatic factors. The knowledge about interference from changes in water temperature in these populations is an important aspect of the epidemiology of schistosomiasis. In this experiment, it is explored the influence of different temperatures on the development of Schistosoma mansoni in Biomphalaria glabrata melanic and albino variants. The results indicated an intrinsic relationship between temperature and development of the parasite in the intramollusc phase, independent of the pigmentation of the mantle of the molluscs. The higher the temperature, the shorter the period necessary for the development of the parasite was while the higher the mortality of infected mollusks. It is concluded that, in the presence of climate change, the increasement of temperature in cold and flooded regions may encourage the establishment of new foci of transmission of schistosomiasis by changing the geographic extent and extending the epidemiological transmission potential. In warm climates, higher temperatures, however, could compromise the transmission of the disease because of biological stress suffered by parasite and host. Under these conditions, it can result in the death of the parasite or a change in their ability to infect new host species of molluscs in new areas. Mantle pigmentation patterns in molluscs have not shown significant interference in the development of the parasite.
\end{abstract}

Keywords: Schistosomiasis, temperature, climate change, pigmentation.

\section{Avaliação de impacto de alterações na temperatura em Biomphalaria glabrata variantes melânica e albina infectadas com Schistosoma mansoni}

\section{Resumo}

Flutuações na densidade populacional de planorbídeos hospedeiros do S. mansoni são influenciadas por fatores climáticos. O conhecimento sobre a interferência de alterações na temperatura da água nestas populações é um aspecto importante da epidemiologia da esquistossomose. Neste experimento avaliou-se a influência de diferentes temperaturas no desenvolvimento de Schistosoma mansoni em Biomphalaria glabrata variantes melânica e albina. Os resultados indicaram uma relação intrínseca entre temperatura e desenvolvimento do parasito na fase intramolusco, independente da pigmentação do manto dos moluscos. Quanto mais elevada a temperatura, menor o período necessário para desenvolvimento do parasito e maior mortalidade dos moluscos infectados. Conclui-se que, na presença de alterações climáticas, o aumento da temperatura em regiões frias e alagadas poderá favorecer o estabelecimento de novos focos de transmissão da esquistossomose alterando a extensão geográfica e ampliando o potencial epidemiológico da transmissão. Em regiões de clima quente, o aumento da temperatura, por sua vez, poderá comprometer a transmissão da doença em virtude do estresse biológico sofrido por parasito e hospedeiro. Nestas condições, poderá ocorrer a morte do parasito ou uma alteração na sua habilidade de infectar novas espécies de moluscos hospedeiros em novas áreas. Padrões de pigmentação do manto nos moluscos não demonstraram interferência significativa no desenvolvimento do parasita.

Palavras-chave: Esquistossomose, temperatura, alteração climática, pigmentação. 


\section{Introduction}

Climate change can be interpreted as changes in climate caused by natural phenomena or by human activities (McMichael et al., 2006; Marcelino, 2008; OPAS, 2009). The consequences of these changes concerning the health of human populations still are being studied, with increased forecast in the incidence of infectious and parasitic diseases because of the sensitivity of biological systems to climate variables such as temperature, precipitation and humidity (Haines et al., 2006; McMichael et al., 2006).

The existence of a casual relationship between climate change and conditions for parasitism changes in the prevalence and intensity of existing infections in addition to the possibility of changes in the geographical distribution of new infections (Githeko et al., 2000).

The relationship between climate change and human health is drawing attention of monitoring and control institutions, with special attention to vector-borne diseases (Cook, 1992; Mas-Coma et al., 2008; Kumar and Kumar, 2013).

The schistosomiasis is a parasitic disease, neglected and debilitating, widespread, caused by trematode Schistosoma mansoni (Morgan et al., 2001). The transmission of this disease is closely related to environmental conditions and the presence of Biomphalaria molluscs, which act as intermediate hosts (Jarne et al., 2011).

Climatic factors, especially precipitation and temperature, exert a strong influence on the epidemiology of the disease, promoting a selective pressure on the mollusc/parasite relationship that occurs in a specified threshold of ambient temperature (OPAS, 2009).

In scenarios with climate change, especially where it is noticed an increased environmental temperature, the epidemiology of schistosomiasis will be directly influenced (Githeko et al., 2000).

Understandment of the patterns of disease transmission in disturbed habitats and how the mollusc/parasite relationship responds to temperature variability will increase our ability to assume our answers and can assist in developing effective programs to control the disease, since, despite the existence of the chemotherapy treatment, the high ecological risk of reinfection negates the beneficial effects of the medicinal product (King, 2009; Paull et al., 2015).

The aim of this study was to evaluate the influence of temperature on the development of S. mansoni in B. glabrata considering also the mantle color variants of the molluscs.

\section{Material and Methods}

In the experiments we used adult specimens of B. glabrata, melanic and albino variants, descendants of populations gathered in Belo Horizonte, Brazil, held at the Department of Animal Biology at the State University of Campinas.

Concerning the infection of the molluscs, there were used 120 melanic and 120 albinos which were individually exposed to 10 miracidia of $S$. mansoni from the BH strain, sympatric, in vials containing $10 \mathrm{~mL}$ of dechlorinated water at a two-hour period under the action of artificial light and heat (temperature of $28^{\circ} \mathrm{C}$ ).

After exposure to the miracidia, the melanic specimens were divided into three groups with 40 molluscs each. The same procedure was performed with albino specimens. Now formed, one with melanic specimens and one with albino, these groups were transferred to air-conditioned greenhouses with controlled temperature and photoperiod and kept at constant temperature of $17^{\circ} \mathrm{C}, 25^{\circ} \mathrm{C}$ and $35^{\circ} \mathrm{C}$.

After twenty days of exposure of the mollusc with miracidia, individual weekly observations were made to determine the rate of infection, the prepatent period and mollusc mortality rate. Observations were made by thirteen weeks.

For the analysis of data, there were used an analysis of differences according to pigmentation variants (melanic and albino) and temperature $\left(17^{\circ} \mathrm{C}, 25^{\circ} \mathrm{C}\right.$ and $\left.35^{\circ} \mathrm{C}\right)$ as a source of variation and interaction.

\section{Results}

Regarding survival, the results indicated a direct relationship to the temperature of which the molluscs were kept. There was a significant difference $(p=0.0308)$ between the temperatures tested. Higher temperatures resulted in lower survival (Figure 1). There could not be observed a significant difference $(\mathrm{p}=0.4818)$ considering the pigmentation of the mollusc mantle.

Mollusc infectivity was not observed at a temperature of $17{ }^{\circ} \mathrm{C}$. When considering the temperatures of $25^{\circ} \mathrm{C}$
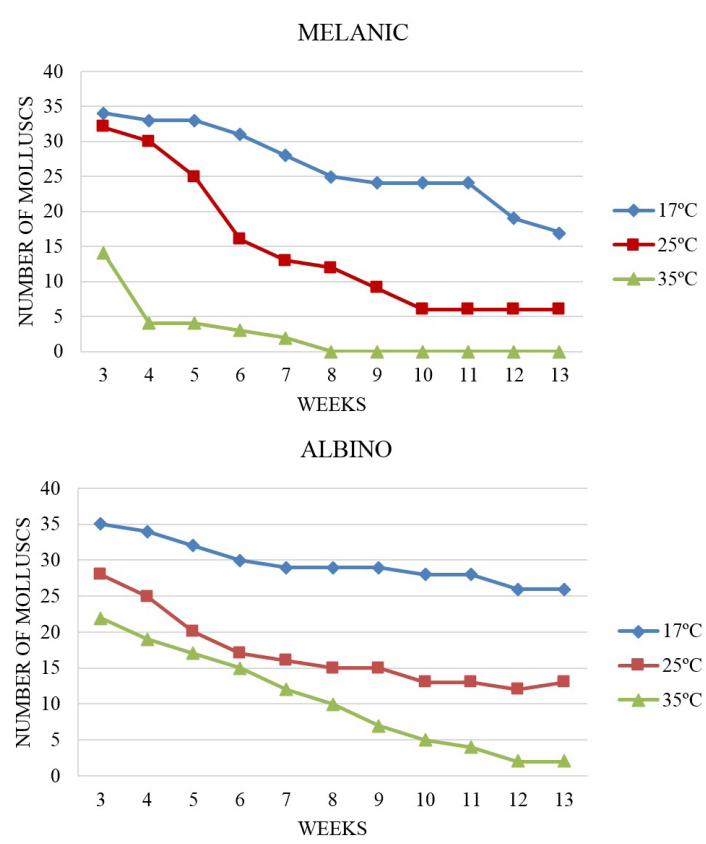

Figure 1. Relationship between temperature and survival rate on specimens of Biomphalaria glabrata melanic and albino variants infected with Schistosoma mansoni. 
and $35^{\circ} \mathrm{C}$, a significant difference was observed between melanic and albino specimens $(\mathrm{p}=0.0001)$ (Table 1$)$.

In relation to the pigmentation variants of the molluscs' mantle, despite the melanic specimens presenting greater infection rates than the albino specimens, the difference between the variants cannot be considered statistically significant $(\mathrm{p}=0.07)$.

The prepatent period is characterized as the period required between exposure to miracidia and the beginning of the elimination of cercariae on the molluscs, ie the time required for development of the parasite in the intermediate host. In this study, there was no elimination of cercariae at $17^{\circ} \mathrm{C}$ and therefore it was not possible to determinate the prepatent period at this temperature. At $35^{\circ} \mathrm{C}$ however, the elimination of cercariae occurred in a time period smaller than at $25{ }^{\circ} \mathrm{C}$, with a significant difference between the temperatures $(\mathrm{p}=0.0004)$, but not between melanic and albino variants $(\mathrm{p}=0.7828)$ (Table 1$)$.

At $25^{\circ} \mathrm{C}$, the prepatent period of the melanic variant ranged between 34 and 52 days and, for the albino variant, this period ranged between 38 and 80 days.

At $35^{\circ} \mathrm{C}$, the prepatent period ranged between 20 and 55 days for the albino variant and 20 days for the melanic variant, there not being observed specimens eliminating cercariae in another period (Figure 2).

The prepatent period observed relates to the period of which the mollusc remained eliminating cercariae. In this experiment, this period considered weekly observations being made.

It was not possible to determinate the patency of the molluscs at $17^{\circ} \mathrm{C}$ due to non-occurrence of elimination of cercariae. At $25{ }^{\circ} \mathrm{C}$ the melanic specimens remained eliminating cercariae for 4.35 weeks. In contrast, albino specimens, at the same temperature, eliminated cercariae in a much shorter period, only 1.75 weeks. At $35^{\circ} \mathrm{C}$ the patency observed in melanic specimens was 0.7 week and 1.78 weeks to albino specimens (Table 1). For the temperatures of $25^{\circ} \mathrm{C}$ and $35^{\circ} \mathrm{C}$ a significant difference was observed $(\mathrm{p}=0.0001)$ between melanic and albino specimens.

Figure 3 presents the pattern of cercariae elimination of the molluscs on each week of the experiment.

\section{Discussion}

Variations on the pattern of pigmentation on the molluscs' mantles are genetic and can influence the susceptibility of molluscs (Chquiloff et al., 1978; Allegretti et al., 2009).
Previous studies suggest that the biochemistry of the melanin can interfere in the defense mechanisms of molluscs, so that melanic specimens show higher susceptibility to being infected by the Schistosoma mansoni when compared to albino specimens (Allegretti et al., 2009).

Our results on the effect of temperature did not allow a significative change between melanic and albino

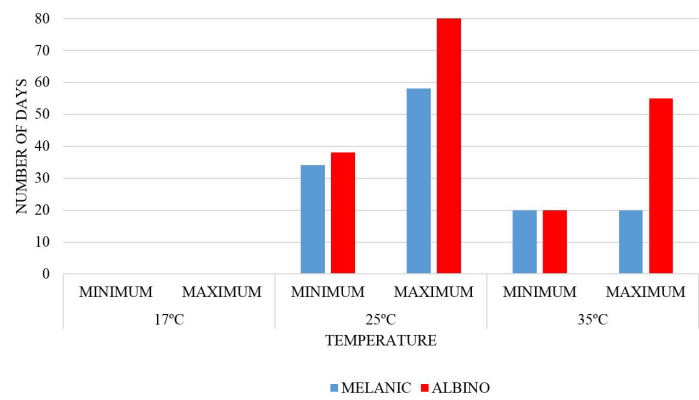

Figure 2. Relationship between temperature and limits for the prepatent period on Biomphalaria glabrata melanic and albino variants infected with Schistosoma mansoni.

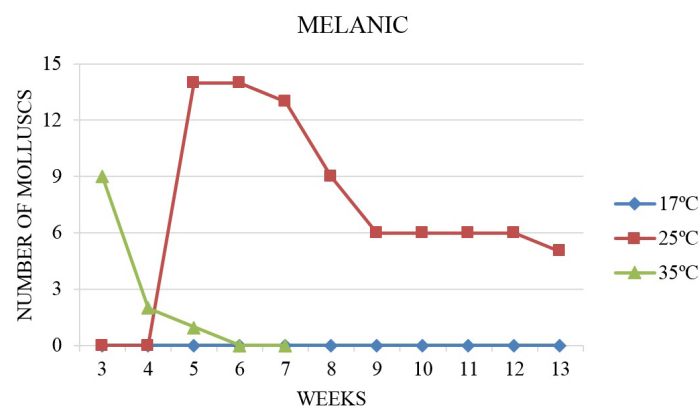

ALBINO

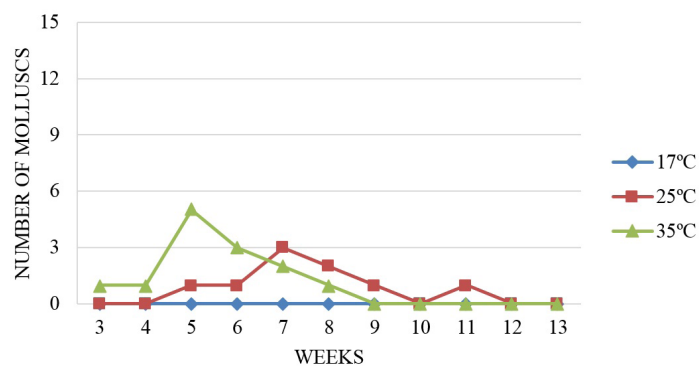

Figure 3. Relationship between temperature and specimens eliminating cercariae on Biomphalaria glabrata melanic and albino variants infected with Schistosoma mansoni.

Table 1. Influence of temperature from biological parameters of Biomphalaria glabrata melanic and albino variants infected with Schistosoma mansoni.

\begin{tabular}{|c|c|c|c|c|c|c|c|c|c|c|c|c|}
\hline \multirow[t]{2}{*}{ B. glabrata } & \multicolumn{3}{|c|}{ Survival rate (\%) } & \multicolumn{3}{|c|}{ Infection rate (\%) } & \multicolumn{3}{|c|}{$\begin{array}{l}\text { Prepatent period } \\
\text { (weeks) }\end{array}$} & \multicolumn{3}{|c|}{$\begin{array}{l}\text { Patency observed } \\
\text { (weeks) }\end{array}$} \\
\hline & $17^{\circ} \mathrm{C}$ & $25^{\circ} \mathrm{C}$ & $35^{\circ} \mathrm{C}$ & $17^{\circ} \mathrm{C}$ & $25^{\circ} \mathrm{C}$ & $35^{\circ} \mathrm{C}$ & $17^{\circ} \mathrm{C}$ & $25^{\circ} \mathrm{C}$ & $35^{\circ} \mathrm{C}$ & $17^{\circ} \mathrm{C}$ & $25^{\circ} \mathrm{C}$ & $35^{\circ} \mathrm{C}$ \\
\hline Melanic & 45.0 & 12.5 & 0 & 0 & 42.5 & 22.5 & 0 & 34 & 20 & 0 & 4.35 & 0.70 \\
\hline Albino & 65 & 27.5 & 5 & 0 & 10 & 17.5 & 0 & 38 & 20 & 0 & 1.75 & 1.78 \\
\hline
\end{tabular}

$\mathrm{n}=40$ molluscs for each temperature and each variant. 
specimens concerning the infection and survival rates along with the prepatent period. Only the patent period, ie the period the molluscs remained eliminating cercariae demonstrated a significant difference between the melanic and albino variants.

The compatibility observed on the Biomphalaria/ Schistosoma relationship is highly specific and environmental factors are important in the development of the trematode on the intramollusc phase (Webbe, 1967). Climatic variations, especially those related to temperature, have a direct relationship with the mollusc infection rate (Wagner and Moore, 1959; Coelho and Bezerra, 2006; McCreesh et al., 2014).

Higher temperatures cause energetical stress and progressive reduction of the physiological performance in parasites and hosts. However, due to adaptive advantages characteristics of the parasitic phenomenon, the thermal acclimation in parasites tends to be a milder event (Paull et al., 2015).

The results of this study confirmed that temperature is an important exogenous factor on the population dynamic of B. glabrata, affecting patterns of mortality and infectivity of the population analyzed, regardless of coloration of the molluscs' mantle - melanic or albino.

In melanic specimens, at the temperature of $17{ }^{\circ} \mathrm{C}$, there was no specimen eliminating cercariae and $45 \%$ of the infected molluscs remained alive until the end of the experiment. At a temperature of $25{ }^{\circ} \mathrm{C}$, the number of specimens eliminating cercariae was equal to $42.5 \%$, though only $12.5 \%$ remained alive. With the experiment being developed at an even higher temperature of $35^{\circ} \mathrm{C}$, only $22.5 \%$ of the infected molluscs eliminated cercariae and none remained alive by the end of the experiment.

Similarly, in albino specimens at a temperature of $17{ }^{\circ} \mathrm{C}$, no molluscs eliminated cercariae and the survival rate was $65 \%$. At $25{ }^{\circ} \mathrm{C}, 10 \%$ of the infected molluscs eliminated cercariae and from the total of infected molluscs, $27.5 \%$ remained alive by the end of the experiment. At a temperature of $35^{\circ} \mathrm{C}, 17.5 \%$ of the infected molluscs eliminated cercariae during the experiment and from all the infected, only 5\% remained alive.

The parasitism exercised by the Schistosoma mansoni and its development on Biomphalaria mollusc consumes a high percentage of biomass and energy from the host. However, at higher temperatures, little stressful, there may be an increased reproduction of the parasite due to the maintenance of energy levels of the host (Paull et al., 2015). Besides that, previous studies concerning the relationship between temperature with the development of the Schistosoma on the mollusc indicate as optimal threshold temperatures between $23^{\circ} \mathrm{C}$ and $28^{\circ} \mathrm{C}$ (Standen, 1951; Stirewalt, 1954).

It is inferred then that the development of Schistosoma on molluscs at the temperatures of $25^{\circ} \mathrm{C}$ and $35^{\circ} \mathrm{C}$ could have influenced the survival of the molluscs. Specifically in melanic molluscs, a temperature of $35^{\circ} \mathrm{C}$ can be considered as highly stressful, for there was an observed increasement on the mortality rate on the infected and a decreasement on the infection rate and the patent period.

Global climate models based on mathematical analyzes are useful and consist of tools available to project future scenarios related to potential climate changes. However, they have some limitations, for they simplify the impacts and assume a constant temperature value (Ghini et al., 2007), not considering intrinsic factors of the molluscs, such as susceptibility, age, immunological mechanisms and geographic distribution. This study offers real data on the impact of the water temperature on the schistosomiasis and aims to provide insights for future studies on this topic.

Our results indicated that changes on the global temperature will affect ecological and biological aspects of the parasite/host relationship between Schistosoma/ Biomphalaria. Such changes will lead to important changes in the distribution, availability and susceptibility of molluscs, allowing that altered areas - previously unaffected - provide adequate abiotic resources for the development of molluscs and their parasites, especially considering temperature increasement in flooded areas with lower temperatures.

In warm climates, however, the increase in ambient temperature can stop the parasite cycle due to biological stress, resulting in possibilities of new specimens of molluscs becoming hosts for the parasite and/or searches for new geographical areas.

\section{Conclusions}

Considering that the projected changes on climate are being confirmed and are including new projections of possible episodes with climatic variability and, recognizing that the species, according to their adaptive abilities, answer in particular ways to the changes, this study suggests that increasement of the temperature of aquatic environments may favor the transmission of schistosomiasis in cold climates and serve as a hindrance for the transmission in warm climates.

In these scenarios, pattern of pigmentation on the mantle of the molluscs, however, do not show significant interference on the transmission and distribution of the disease.

\section{References}

ALLEGRETTI, S.M., CARVALHO, J.F., MAGALHÃES, L.A. and ZANOTTI-MAGALHÃES, E.M., 2009. Behaviour of albino and melanic variants of Biomphalaria glabrata Say, 1818 (Mollusca: Planorbidae) following infection by Schistosoma mansoni Sambon, 1907. Brazilian Journal of Biology = Revista Brasileira de Biologia, vol. 69, no. 1, pp. 217-222. http://dx.doi. org/10.1590/S1519-69842009000100029.

CHQUILOFF, M.A.G., SCHERRER, J.F. and FREITAS, J.R., 1978. Estudo preliminar das variedades xadrezadas de Biomphalaria glabrata (Say, 1818) em confronto com as variedades pigmentada e albina. Revista do Instituto de Medicina Tropical de São Paulo, vol. 20, no. 1, pp. 22-30. PMid:653218. 
COELHO, J.R. and BEZERRA, F.S., 2006. The effects of temperature change on the infection rate of Biomphalaria glabrata with Schistosoma mansoni. Memórias do Instituto Oswaldo Cruz, vol. 101, no. 2, pp. 223-224. http://dx.doi.org/10.1590/S007402762006000200016 . PMid:16830717.

COOK, G.C., 1992. Effect of global warming on the distribution of parasitic and other infectious diseases: a review. Journal of the Royal Society of Medicine, vol. 85, no. 11, pp. 688-691. PMid:1474555.

GHINI, R., HAMADA, E., GONÇALVES, R.R.V., GASPAROTTO, L. and PEREIRA, J.C.R., 2007. Análise de risco de mudanças climáticas globais sobre a Sigatoka-negra da bananeira no Brasil. Fitopatologia Brasileira, vol. 32, no. 3, pp. 197-204. http://dx.doi. org/10.1590/S0100-41582007000300003.

GITHEKO, A.K., LINDSAY, S.W., CONFALONIERI, E.U. and PATZ, J.A., 2000. Climate change and vector-borne diseases: a regional analysis. Bulletin of the World Health Organization, vol. 78, no. 9, pp. 1136-1147. PMid:11019462.

HAINES, A., KOVATS, R.S., CAMPBELL-LENDRUM, D. and CORVALAN, C., 2006. Climate change and human health: impacts, vulnerability and public health. Public Health, vol. 120, no. 7, pp. 585-596. http://dx.doi.org/10.1016/j.puhe.2006.01.002. PMid:16542689.

JARNE, P., POINTIER, J.P. and DAVID, P., 2011. Biosystematics of Biomphalaria spp. With na emphasis on Biomphalaria glabrata. In: R. TOLEDO and B. FRIED, editors. Biomphalaria snails and larval trematodes. New York: Springer, pp. 1-32.

KING, C.H., 2009. Global health: toward the elimination of schistosomiasis. The New England Journal of Medicine, vol. 360, no. 2, pp. 106-109. http://dx.doi.org/10.1056/NEJMp0808041. PMid:19129524.

KUMAR, S. and KUMAR, R., 2013. Environment change: broaden of diseases. International Journal of Current Microbiology and Applied Sciences, vol. 2, no. 5, pp. 60-66.

MARCELINO, E.V., 2008 [viewed 8 October 2015]. Desastres naturais e geotecnologias: conceitos básicos [online]. Santa Maria: CRS/INPE. Caderno Didático, no. 1. INPE-15208-PUD/193. Available from: http://mtc-m18.sid.inpe.br/col/sid.inpe.br/ mtc-m18@80/2008/07.02.16.22/doc/publicacao.pdf

MAS-COMA, S., VALERO, M.A. and BARGUES, M.D., 2008. Effects of climate change on animal and zoonotic helminthiasis.
Scientific and Technical Review of the Office International des Epizooties, vol. 27, no. 2, pp. 443-457. http://dx.doi.org/10.20506/ rst.27.2.1822. PMid:18819671.

MCCREESH, N., ARINAITWE, M., ARINAITWE, W., TUKAHEBWA, E.M. and BOOTH, M., 2014. Effect of water temperature and population density of the population dynamics of Schistosoma mansoni intermediate host snails. Parasites \& Vectors, vol. 7, pp. 503. PMid:25388819.

MCMICHAEL, A.J., WOODRUFF, R.E. and HALES, S., 2006. Climate change and human health: present and future risks. Lancet, vol. 367, no. 9513, pp. 859-869. http://dx.doi.org/10.1016/S01406736(06)68079-3. PMid:16530580.

MORGAN, J.A.T., DEJONG, R.J., SNYDER, S.D., MKOJI, G.M. and LOKER, E.S., 2001. Schistosoma mansoni and Biomphalaria: past history and future trends. Parasitology, vol. 123, no. 7, suppl., pp. S211-S228. http://dx.doi.org/10.1017/S0031182001007703. PMid:11769285.

ORGANIZAÇÃO PAN-AMERICANA DA SAÚDE - OPAS, 2009. Mudança climática e saúde: um perfil do Brasil. Brasília: Organização Pan-Americana da Saúde. 44 p.

PAULL, S.H., RAFFEL, T.R., LAFONTE, B.E. and JOHNSON, P.T.J., 2015. How temperature shifts affect parasite production: testing the roles of thermal stress and acclimation. Functional Ecology, vol. 29, no. 7, pp. 941-950. http://dx.doi.org/10.1111/13652435.12401 .

STANDEN, O.D., 1951. The effect of temperature, light and salinity upon the hatching of the ova of Schistosoma mansoni. Transactions of the Royal Society of Tropical Medicine and Hygiene, vol. 45, no. 2, pp. 225-241. http://dx.doi.org/10.1016/ S0035-9203(51)90917-0. PMid:14893440.

STIREWALT, M.A., 1954. Effect of snail maintenance temperatures on development of Schistosoma mansoni. Experimental Parasitology, vol. 3, no. 6, pp. 504-516. http://dx.doi.org/10.1016/00144894(54)90046-6. PMid:13210368.

WAGNER, E.D. and MOORE, B., 1959. The development of Schistosoma mansoni in snails kept at certain constant temperatures. Transactions of the American Microscopical Society, vol. 78, no. 4, pp. 424-428. http://dx.doi.org/10.2307/3224159.

WEBBE, G., 1967. The effect of different environmental factors on transmission of bilharziasis. Annales de la Société Belge de Medecine Tropicale, vol. 47, no. 1, pp. 97-106. PMid:5624742. 